Acta Agroph., 2019, 26(4), 31-38

doi: $10.31545 /$ aagr/116644

\title{
THE INFLUENCE OF AMINO ACID BIOSTIMULATORS ON THE SIZE AND QUALITY OF GARLIC (ALLIUM SATIVUM L.)
}

\author{
Joanna Majkowska-Gadomska1 ${ }^{1}$, Emilia Mikulewicz ${ }^{1}$, \\ Krzysztof Jadwisieńczak ${ }^{2}$, Anna Francke ${ }^{1}$, Kinga Mtyńska ${ }^{1}$ (]) \\ ${ }^{1}$ Department of Horticulture, University of Warmia and Mazury in Olsztyn \\ Prawocheńskiego 21, 10-957, Olsztyn, Poland \\ ${ }^{2}$ Department of Working Machines and Methodology of Research, University of Warmia and Mazury \\ in Olsztyn, Prawocheńskiego 21, 10-957, Olsztyn, Poland \\ e-mail: emilia.mikulewicz@uwm.edu.pl
}

\begin{abstract}
A field experiment was conducted in the years 2017-2018 in the area of the Didactic and Experimental Centre, University of Warmia and Mazury in Olsztyn. The experiment was set up in the randomised split block design, in three replicates. The first experimental factor was four winter cultivars of garlic (Allium sativum L.): 'Arkus', 'Harnaś', 'Mega', 'Ornak'. Within the scope of the second experimental factor, the effect of amino acid biostimulators Calleaf Aminovital and Maximus Amino Protect on the yield and quality of garlic was analysed. The control treatment comprised plots on which only water was applied. The objective of the study was to estimate selected morphological features of bulbs and the content of nutritional components of garlic cultivated with the use of biopreparations. The morphology and the nutritional composition of the edible part of garlic was estimated. Statistically significant impact of the cultivar on bulb mass and horizontal diameter and on the content of L-ascorbic acid and nitrates (V) in the edible part of garlic was demonstrated. Cultivar 'Ornak' was characterised by greater bulb mass $(64.62 \mathrm{~g})$, vertical and horizontal diameter $(4.09$ and $4.14 \mathrm{~cm})$, dry matter content

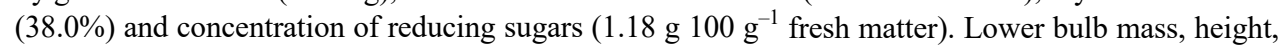
content of total and reducing sugars and of nitrates $(\mathrm{V})$ were determined in garlic cv. 'Arkus'. The cultivation of garlic plants with the use of the biostimulators had a significant effect on the number of cloves in a single bulb. The application of Calleaf Aminovital increased their number to an average of 6 cloves $\times$ plant $^{-1}$. Interaction of garlic plants cv. 'Arkus' with Calleaf Aminowital significantly reduced the content of nitrates (V) in garlic relative to the remaining cultivation treatments.
\end{abstract}

Keyw ord s: nutritional value, biometry, Allium sativum L, amino acid biostimulators 


\section{INTRODUCTION}

Garlic (Allium sativum L.) is one of the oldest plants cultivated by Man. Due to its taste and health-promoting values is has become an essential component in human diet all over the world (Matłok et al. 2014). The nutritional and health values of garlic result from its high content of biologically active substances, the concentration of which depends on ensuring suitable conditions of growth and development for the plants during the period of vegetation (Matysiak et al. 2015). For this purpose, apart from chemical plant protection agents, qualified preparations referred to as biostimulators are applied. Their primary function is to protect plants against stress, and to stimulate their growth and regeneration. According to Mystkowska (2018), the use of foliar-applied biostimulators is an intervention treatment which prevents reductions in the yields of crop plants. Calleaf Aminovital and Maximus Amino Protect are biological preparations in the form foliar-applied fertilisers with a string anti-stress effect. Free amino acids contained in the preparations affect the synthesis of proteins, participating in enzymatic reactions in plants and stimulating their resistance (Gugała et al. 2017).

The objective of the study presented here was to estimate the morphological features of bulbs and the content of selected nutritional components of four winter garlic cultivars cultivated with the use of biopreparations.

\section{MATERIAL AND METHOD}

The study conducted in the years 2017-2018 comprised morphological assessment and determination of the content of selected biological components in garlic. The experiment was conducted in the garden of the Didactic and Experimental Centre of the University of Warmia and Mazury in Olsztyn, with the method of randomised blocks, in three replicates, on brown soils classified in Class IVb. The experimental material consisted on winter cultivars of garlic - 'Arkus', 'Harnaś', 'Mega' and 'Ornak', purchased from the company Polan. The garlic cultivars were the first experimental factor in the study. Within the scope of the second factor, the effect of the preparations Calleaf Aminovital and Maximus Amino Protect on the yields, morphology and on the content of nutritional components was analysed. The preparations were applied at equal doses of $0.3 \%$, beginning from the first half of April till the middle of May, at 7-day intervals. The control treatment consisted of plots sprinkled with distilled water. The volume of the working liquid applied at one time was 300 litres per hectare. The standard LU spray nozzle was used (flat-spray, fine-droplet). Cloves were planted every year, in the second decade of October in the year preceding the vegetation season of garlic, on plots with area of $1 \mathrm{~m}^{2}$, at spacing of $0.1 \times 0.1 \mathrm{~m}$. Soil preparation, fertilisation and cultivation treatments were conducted in conformance 
with the Methodology of integrated production of garlic (Anyszka et al. 2020). The application of the biopreparations began in the second decade of May and it was repeated four times at 14-day intervals. After the harvest in the last decade of August, drying and cleaning of dried leaves, the commercial yield was estimated. Samples of material were collected from the commercial yield, and an averaged sample was prepared from each experimental treatment. The samples of the material of the analysed garlic cultivars were subjected to morphological analysis and to determination of the content of selected chemical compounds. The mass, height and width of the bulb were determined, and the number of cloves in the bulb. The determinations of the chemical composition were performed at the laboratory of the Department of Horticulture. The air-dry matter content was determined by drying the biomass at temperature of $60^{\circ} \mathrm{C}$. The content of total and reducing sugars was determined with the Luff-Schoorl method (PN-90/A-75101/07); the content of L-ascorbic acid - with the Tillmans method as modified by Pijanowski (Determination of the content... PN90/A-75101/11). Total acidity was given in conversion to malic acid (Determination of total acidity, PN-90A-75101/04). The content of nitrates (V) was assayed with the colorimetric method, with the use of salicylic acid.

All determinations were made in three replicates. The significance of differences between mean values was tested with the Tukey test for randomised sub-blocks in a two-factor design, calculating semi-intervals of confidence at significance level of $\alpha=0.05$. The statistical calculations were made using the program STATISTICA 13 .

\section{RESULTS AND DISCUSSION}

The analysed cultivars of garlic differed significantly in the mass of the bulbs - from 39.65 to $64.62 \mathrm{~g}$. The lowest bulb mass was characteristic of plants of cultivars 'Arkus' and 'Harnaś', and the highest of cultivar 'Ornak'. The application of the biostimulators did not differentiate the analysed feature. As a result of the interaction, a higher mean mass of bulb was noted in the cultivation of plants of cultivar 'Ornak' in all the variants of cultivation, relative to the remaining experimental treatments. An earlier study by Yeshiwas et al. (2018) showed a considerably lower garlic bulb mass, varying from 4.87 to $17.51 \mathrm{~g}$, and in a study by Albuquerque et al. (2017) - from 7.57 to $14.47 \mathrm{~g}$.

The analysed factors and their interactions did not significantly differentiate the height of garlic bulb. A higher value of that feature was noted in the cultivation of plants of cv. 'Ornak' $(4.16 \mathrm{~cm})$, and a lower value in plants of cv. 'Arkus' $(3.21 \mathrm{~cm})$, in treatments with the use of Maximus Amino Protect. The cultivar of garlic statistically significantly differentiated the width of garlic bulb which varied from 2.92 to $4.14 \mathrm{~cm}$. Smaller widths were determined in the cultivation of cv. 'Harnaś' 
and 'Arkus', and higher values of that feature in cultivars 'Ornak' and 'Mega'. Similar results were obtained by Albuquerque et al. (2017) $-3.51-3.71 \mathrm{~cm}$, and by Yeshiwas et al. (2018) - 2.10-3.80 cm.

Yeshiwas et al. (2018) report that the mass of a clove of garlic varies from 0.26 to $1.50 \mathrm{~g}$ depending on the cultivar. Our study showed that clove mass was from 10.57 to $14.35 \mathrm{~g}$, depending on the cultivar and the preparation applied, but statistical analysis did not confirm such a relationship.

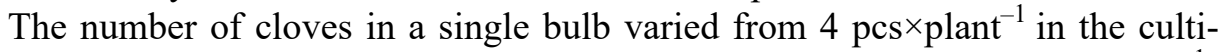
vation of garlic plants with the use of Maximus Amino Protect to 7 pcs $\times$ plant $^{-1}$. Interaction of factors had a favourable effect on the number of cloves in a bulb of garlic cv. 'Ornak' from the treatment with Calleaf Aminovital $\left(7 \mathrm{pcs} \times\right.$ plant $\left.^{-1}\right)$, compared with the remaining experimental treatments. An earlier study by Petropoulsos et al. (2018) showed that the number of cloves in a garlic bulb, depending on the

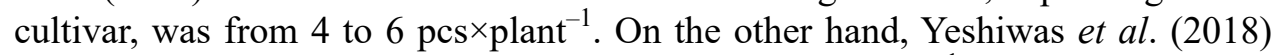
obtained somewhat higher results - from 10 to $20 \mathrm{pcs} \times$ plant $^{-1}$, while Albuquerque et al. (2017) - from 6 to 22 pcs $\times$ plant $^{-1}$.

Dry matter content in the analysed garlic cultivars was in the range from 30.65 to $38.05 \%$. Garlic cv. 'Ornak' and 'Mega' was characterised by greater dry matter content in the edible part, compared with cultivars 'Harnas' and 'Arkus'. Similar results were obtained by other authors. Ciuba at al. (2016) compared the chemical composition of several garlic cultivars and obtained for following dry matter levels in cultivars: 'Arkus' - 34.69\%; 'Harnaś' - 38.49\%; 'Mega' - 37.11\% and 'Ornak' - 37.70\%. On the other hand, Marcińca and Włodarczyk-Marciniec (2008) obtained dry matter content of 37.00\%, while Petropoulsos et al. (2018) - 31.67-42.64\%. A higher content of dry matter was characteristic of garlic analysed by Suleria et al. (2015) - 46.505.

No significant effect of the factors and their interactions on the content of sugars in garlic was demonstrated. The analysed cultivars had an average content of

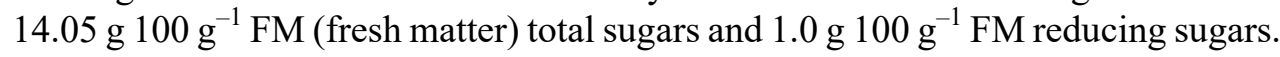
A higher level of total sugars was assayed in material of cv. 'Mega' in the control

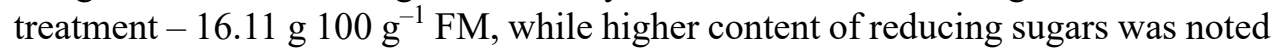
in material of the same cultivar, obtained from the treatment with Maximus Amino Protect $-1.19 \mathrm{~g} 100 \mathrm{~g}^{-1} \mathrm{FM}$. Lower levels of the analysed components were noted in garlic cv. 'Arkus' in the control treatment, at 12.93 and $0.88 \mathrm{~g} \cdot 100 \mathrm{~g}^{-1} \mathrm{FM}$, respectively. In an earlier study, Ciuba et al. (2016) obtained similar results of total

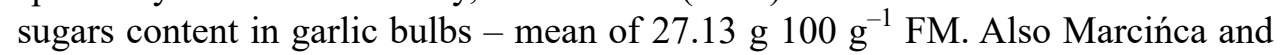
Włodarczyk-Marciniec (2008) obtained a similar content of the analysed compo-

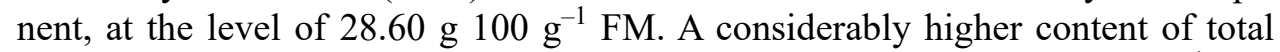

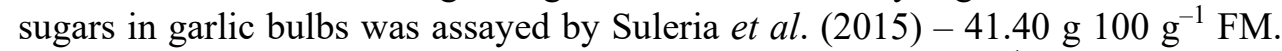

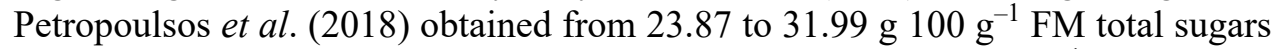

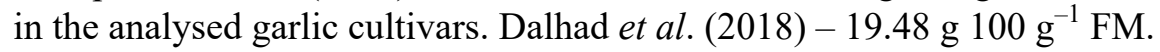


Table 1. The influence of biostimulators on biometric features of garlic (Allium sativum L.)

\begin{tabular}{|c|c|c|c|c|c|c|}
\hline \multirow{2}{*}{ Cultivar } & \multirow{2}{*}{ Biostimulator } & \multirow{2}{*}{$\begin{array}{c}\text { Mass } \\
\mathrm{g}\end{array}$} & Height & Width & \multirow{2}{*}{$\begin{array}{c}\text { Clove mass } \\
\mathrm{g}\end{array}$} & \multirow{2}{*}{$\begin{array}{c}\text { No. of cloves } \\
\text { pcs } \times \text { plant }^{-1}\end{array}$} \\
\hline & & & \multicolumn{2}{|c|}{$\mathrm{cm}$} & & \\
\hline \multirow[t]{4}{*}{ 'Mega' } & $\mathrm{K}^{*}$ & 48.54 & 3.80 & 3.24 & 11.58 & 4.0 \\
\hline & $\mathrm{CA}$ & 46.51 & 3.97 & 4.03 & 13.21 & 5.5 \\
\hline & MAP & 50.93 & 3.78 & 3.96 & 14.35 & 4.5 \\
\hline & Mean & 48.66 & 3.85 & 3.74 & 13.04 & 4.6 \\
\hline \multirow[t]{4}{*}{ ‘Ornak’ } & K & 71.82 & 4.04 & 4.23 & 14.20 & 5.5 \\
\hline & $\mathrm{CA}$ & 57.52 & 4.09 & 4.24 & 12.08 & 7.0 \\
\hline & MAP & 64.53 & 4.16 & 3.96 & 12.52 & 4.0 \\
\hline & Mean & 64.62 & 4.09 & 4.14 & 12.93 & 5.5 \\
\hline \multirow[t]{4}{*}{ 'Arkus' } & K & 38.01 & 3.45 & 2.84 & 11.80 & 4.5 \\
\hline & $\mathrm{CA}$ & 39.75 & 3.38 & 3.36 & 10.57 & 6.0 \\
\hline & MAP & 41.2 & 3.21 & 3.04 & 13.39 & 4.0 \\
\hline & Mean & 39.65 & 3.35 & 3.08 & 11.92 & 4.8 \\
\hline \multirow[t]{4}{*}{ 'Harnaś' } & K & 35.46 & 3.42 & 2.85 & 10.96 & 5.5 \\
\hline & $\mathrm{CA}$ & 47.16 & 3.22 & 3.07 & 10.89 & 5.0 \\
\hline & MAP & 46.63 & 3.46 & 2.83 & 11.11 & 5.5 \\
\hline & Mean & 43.08 & 3.37 & 2.92 & 10.99 & 5.3 \\
\hline \multirow[t]{3}{*}{ Mean } & $\mathrm{K}$ & 48.46 & 3.68 & 3.29 & 12.13 & 6.5 \\
\hline & $\mathrm{CA}$ & 47.73 & 3.66 & 3.68 & 11.69 & 7.8 \\
\hline & MAP & 50.82 & 3.65 & 3.45 & 12.84 & 6.0 \\
\hline & cultivar (a) & 8.74 & n.s. & 0.79 & n.s. & n.s. \\
\hline & biostimulator (b) & n.s. & n.s. & n.s. & n.s. & 0.61 \\
\hline & interaction $(\mathrm{axb})$ & 15.51 & n.s. & n.s. & n.s. & 0.69 \\
\hline
\end{tabular}

*Explanation: $\mathrm{K}$ - control treatment; CA - Calleaf Aminovital; MAP - Maximus Amino Protect; n.s. - not significant.

Ciuba et al. (2016) report that cultivation conditions have a significant impact on the content of L-ascorbic acid in the edible part of garlic. Those authors obtained

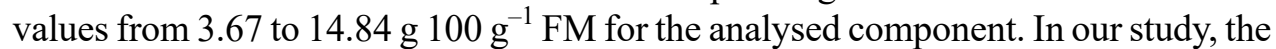

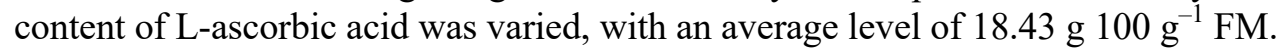
A significantly lower level of the analysed substance, compared to the other cultivars,

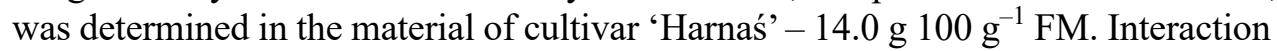
of factors caused an increase of the content of L-ascorbic acid in the edible part of garlic cv. 'Mega' in all the treatments, and of cv. 'Ornak' from the control treatment and from the treatment with the use of Maximus Amino Protect. Significantly lower levels of the analysed substance were assayed in the remaining treatments. In the study by Marcińca and Włodarczyk-Marciniec (2008) the content of L-ascorbic acid

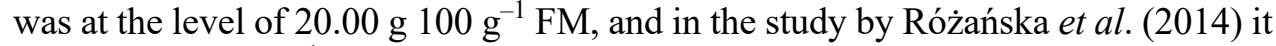

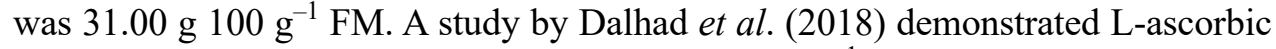

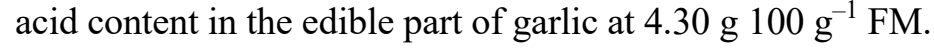


Table 2. The influence of biostimulators on nutritional composition of garlic (Allium sativum L.)

\begin{tabular}{|c|c|c|c|c|c|c|c|}
\hline \multirow[t]{2}{*}{ Cultivar } & \multirow[t]{2}{*}{ Biostimulator } & $\begin{array}{c}\text { Dry } \\
\text { matter }\end{array}$ & $\begin{array}{c}\text { Total } \\
\text { sugars }\end{array}$ & $\begin{array}{l}\text { Reducing } \\
\text { sugars }\end{array}$ & $\begin{array}{l}\text { L-ascorbic } \\
\text { acid }\end{array}$ & $\begin{array}{l}\text { Organic } \\
\text { acids }\end{array}$ & \multirow{2}{*}{$\begin{array}{c}\text { Nitrates } \\
(\mathrm{V})\end{array}$} \\
\hline & & $\%$ & \multicolumn{2}{|c|}{ g $100 \mathrm{~g}^{-1} \mathrm{FM}$} & $\mathrm{mg} 100 \mathrm{~g}^{-1} \mathrm{FM}$ & g $100 \mathrm{~g}^{-1} \mathrm{FM}$ & \\
\hline \multirow{4}{*}{ 'Mega' } & $\mathrm{K}^{*}$ & 37.4 & 16.11 & 0.99 & 21.30 & 0.08 & 238.6 \\
\hline & $\mathrm{CA}$ & 38.1 & 15.50 & 1.15 & 22.20 & 0.06 & 232.5 \\
\hline & MAP & 37.1 & 14.62 & 1.19 & 20.90 & 0.10 & 240.1 \\
\hline & Mean & 37.5 & 15.41 & 1.11 & 21.50 & 0.10 & 237.1 \\
\hline \multirow{4}{*}{ 'Ornak’ } & $\mathrm{K}$ & 39.0 & 13.90 & 1.18 & 21.30 & 0.07 & 266.2 \\
\hline & $\mathrm{CA}$ & 37.6 & 13.54 & 1.18 & 16.30 & 0.08 & 191.6 \\
\hline & MAP & 37.5 & 14.12 & 1.17 & 21.10 & 0.08 & 302.4 \\
\hline & Mean & 38.0 & 13.88 & 1.18 & 19.60 & 0.10 & 253.4 \\
\hline \multirow{4}{*}{ ‘Arkus’' } & $\mathrm{K}$ & 37.1 & 12.93 & 0.88 & 24.20 & 0.05 & 294.3 \\
\hline & $\mathrm{CA}$ & 28.5 & 13.71 & 0.93 & 14.90 & 0.10 & 166.3 \\
\hline & MAP & 33.5 & 13.74 & 0.84 & 16.80 & 0.10 & 235.7 \\
\hline & Mean & 33.0 & 13.46 & 0.88 & 18.60 & 0.10 & 232.1 \\
\hline \multirow{4}{*}{ 'Harnaś' } & $\mathrm{K}$ & 30.0 & 13.62 & 0.97 & 13.70 & 0.10 & 275.7 \\
\hline & $\mathrm{CA}$ & 31.1 & 13.23 & 0.99 & 14.00 & 0.08 & 271.4 \\
\hline & MAP & 30.8 & 13.60 & 0.91 & 14.20 & 0.08 & 283.3 \\
\hline & Mean & 30.6 & 13.48 & 0.96 & 14.00 & 0.10 & 276.8 \\
\hline \multirow{3}{*}{ Mean } & $\mathrm{K}$ & 35.8 & 14.14 & 1.00 & 20.14 & 0.07 & 268.7 \\
\hline & CA & 33.8 & 13.99 & 1.06 & 16.83 & 0.08 & 215.5 \\
\hline & MAP & 34.7 & 14.02 & 1.03 & 18.25 & 0.09 & 265.9 \\
\hline \multicolumn{8}{|c|}{$\mathrm{LSD}_{0.05}$ for: } \\
\hline & cultivar (a) & 3.99 & n.s. & n.s. & 3.03 & n.s. & n.s. \\
\hline & iostimulator (b) & n.s. & n.s. & n.s. & n.s. & n.s. & n.s. \\
\hline
\end{tabular}

*Explanation as in Table 1.

The average content of organic acids in the edible part of garlic was $0.10{\mathrm{~g} 100 \mathrm{~g}^{-1} \mathrm{FM}}^{\mathrm{F}}$ and it was not statistically significantly correlated with the experimental factors and their interactions.

The average content of nitrates (V) in the analysed garlic material was $249.9 \mathrm{NO}_{3} \mathrm{~kg}^{-1} \mathrm{FM}$. A higher level of nitrates was found in the edible part of plants cv. 'Harnaś', and the lowest in those of cv. 'Arkus', at 276.8 and $232.1 \mathrm{NO}_{3} \mathrm{~kg}^{-1} \mathrm{FM}$, respectively. Although the application of Calleaf Aminowital caused a decrease in the level of the analysed substances, no statistically significant effect of the experimental treatments on the level of nitrates $(\mathrm{V})$ was demonstrated. The use of Calleaf Aminowital in the cultivation of cultivar 'Arkus' caused a significant decrease in the level of nitrates (V), to $166.3 \mathrm{NO}_{3} \mathrm{~kg}^{-1} \mathrm{FM}$. Increased condensation of the analysed substances was noted in the plant material from cv. 'Ornak' (302.4 $\mathrm{NO}_{3} \mathrm{~kg}^{-1} \mathrm{FM}$ ) and 'Harnas' (283.3 $\left.\mathrm{NO}_{3} \mathrm{~kg}^{-1} \mathrm{FM}\right)$. Within that statistical group also the plant 
material from cv. 'Arkus' from the control treatment was noted. An earlier study by Gajewska and Czajkowska-Mysłek (2015) showed that the concentration of the analysed substances in garlic material varies from 169.6 to $296.2 \mathrm{NO}_{3} \mathrm{~kg}^{-1} \mathrm{FM}$.

\section{CONCLUSIONS}

1. Greater mass, height and width if bulbs, content of dry matter and of reducing sugars, were characteristic of garlic cultivar 'Ornak'.

2. A positive effect of the preparation Calleaf Aminovital on increased number of cloves in garlic bulb was demonstrated in comparison to the other experimental treatments.

3. Increased levels of the content of reducing sugars and organic acids were assayed in material from plants cultivated with the use of the biostimulators.

Conflict of interest: The Authors does not declare conflict of interest.

\section{REFERENCES}

Anyszka Z., Berniak H., Chałańska A., Łabanowski G., Wrzodak R., Robak J., Włodarek A., 2020. Methodology of integrated garlic production (second edition amended). Integrated Officially Controlled Production (in Polish). Retrieved 5.03.2020 from https://piorin.gov.pl/download/gfx/ piorin/pl/defaultstronaopisowa/1328/1/1/metodyka_ip_czosnku_ed_2.pdf.

Albuquerque J.R.A., Monteiro H.N.B., Bezerra A.A.C., Filho C.H.A., Lopes A.C.A., Gomes R.L.F., 2017. Agromorphological performance of garlic landraces in Piauí, Brazil. Cienc. Rural, 47(6), 2-6, https://doi.org/10.1590/0103-8478cr20160017

Ciuba M., Dziadek K., Kukiełka K., Oczkowicz J., Piątkowska E., Leszczyńska E., Kopeć A., 2016. Comparison of chemical composition and content of bioactive components of selected cultivars of garlic (in Polish). ŻNTJ, 5(108), 107-115.

Dalhad M.H., Adefolake F.A., Musa M., 2018. Nutritional composition and phytochemical analysis of aqueous extract of Allium cepa (onion) and Allium sativa (garlic). Asian Food Sci. J., 3(4), 1-9, https://doi.org/10.9734/AFSJ/2018/43165

Gajewska M., Czajkowska-Mysłek A., 2015. Estimation of the level of contamination with nitrates (III) and (V) of dried spice plants available on the retail market (in Polish). Bromat. Chem. Toksykol., 47(3), 310-315.

Gugała M., Sikorska A., Zarzecka K., Krasnodębska E., Kapela K., Mystkowska I., 2017. Economic viability of the use of growth biostimulators in winter oilseed rape cultivation (in Polish). Roczniki Naukowe Stowarzyszenia Ekonomistów i Agrobiznesu, 19(4), 92-96.

Marcińca K., Włodarczyk-Marciniec B. 2008. Anti-carcinogenic properties of garlic (in Polish). Post. Fitoter., 2, 90-95.

Matłok N., Gorzelany J., Bilek M., Pieniążek R., Kuźniar P., Kaniuczak J., 2014. Estimation of the content of fructose, glucose and saccharose in selected onion cultivars cultivated at three breeding and seed-production farms (in Polish). Zesz. Probl. Post. Nauk Rol., 576, 79-87.

Matysiak M., Gaweł-Bęben K., Rybczyńska K., Gmiński J., Surma S., 2015. Comparison of selected biological properties of garlic (Allium sativum L.) cultivated in Poland and in China (in Polish). ŻNTJ, 2(99), 160-169, https://doi.org/10.15193/zntj/2015/99/030 
Mystkowska I.T., 2018. Biostimulators as a factor affecting the yields of edible potato (in Polish). Acta Agroph., 25(3), 307-315, https://doi.org/10.31545/aagr/95109

Petropoulsos S.A, Fernandes A., Ntatsi G., Petrolos K., Barros L., Ferreira I.C.F.R., 2018. Nutritional value, chemical characterization and bulb morphology of Greek garlic landraces. Molecules, 23, 1-14, https://doi.org/10.3390/molecules23020319

Różańska D., Regulska-Ilow B., Ilow R., 2014. Effect of selected cooking processes on antioxidative potential and content of polyphenols in food (in Polish). PHiE, 95(2), 215-222

Suleria H.A., Butt M.S., Khalid N., Sultan S., Raza A., Aleem M., Abbas M., 2015. Garlic (Allium sativum). Diet based therapy of $21^{\text {st }}$ century: A review. Asian Pac. J. Trop. Dis., 5(4), 271-278, https://doi.org/10.1016/S2222-1808(14)60782-9

Yeshiwas Y., Belete N., Tegibew W., Yohaness G., Melke A., Kassahun Y., 2018. Collection and characterization of garlic (Allium sativa $\mathrm{L}$.) germplasm form growth and bulb yield at Debre Markos, Ethiopia. J. Hortic. For., 10(3), 17-26, https://doi.org/10.5897/JHF2017.0500 